Marquette University

e-Publications@Marquette

$1-1-2016$

Taxing Choices: International Competition, Domestic Institutions and the Transformation of Corporate Tax Policy

Duane Swank

Marquette University, duane.swank@marquette.edu

Accepted version. Journal of European Public Policy, Vol. 23, No. 4 (2016): 571-603. DOI. (C) 2016

Taylor \& Francis. Used with permission. 
Published in Journal of European Public Policy Vol. 23 (No. 4, 2016): 571-603

\title{
Taxing Choices: International Competition, Domestic Institutions and the Transformation of Corporate Tax Policy
}

\author{
Duane Swank
}

\begin{abstract}
Since the 1980s, notable corporate tax base broadening and rate reductions have occurred throughout the rich democracies. Scholars agree that tax competition for mobile assets shapes this transformation. I address two questions in this paper. First, what form has tax competition taken and, second, how have domestic institutions conditioned competition's impact? I build on past work and argue that tax competition is characterized by the (Stackelberg) leadership of the United States as opposed to alternative forms of competition. At the same time, domestic institutions, especially the degree to which the nation is a coordinated versus liberal market economy, are central determinants of the pace of reform. I test these propositions with models of 1982-to-2008 tax rate change in 18 capitalist democracies. I find that rising trade openness and capital mobility place downward pressures on tax rates, the U. S. adoption of the neoliberal tax model engenders significant competitive responses from other nations, and that the institutions of coordinated economies slow the pace of neoliberal reforms. High public debt, left-leaning median voters, and institutional veto points also significantly constrain tax policy change. I conclude with some reflections on tax policy in the wake of the global financial crisis and on neoliberalism and institutional change in advanced democratic capitalism. Keywords: corporate taxation, globalization, institutional change, tax competition, varieties of capitalism
\end{abstract}


Neoliberal reforms in taxation have spread across the developed democracies since the 1980s (e.g., Swank and Steinmo 2002; Genschel and Schwartz 2011). Policy makers have altered tax rates, the relative emphasis on equity and efficiency, and the use of tax policy to accomplish collective goals: corporate and personal income tax rates were scaled back, the number of brackets was cut and inflation-indexed, and many tax credits, allowances and exemptions were scaled back to broaden the tax base. Trends toward market-friendly tax structure have been pronounced for corporate income taxation (Ganghoff 2004).

In the current paper, I extend my past work (Swank and Steinmo 2002; Swank 2006) and address the question of why developed nations shifted to market-conforming corporate tax policy. ${ }^{1}$ Past research offers some answers. The "first generation" of studies on the tax impacts of globalization has shown that trade openness and capital mobility hasten cuts in statutory and effective corporate tax rates (see Leibrecht and Hochgatterer 2012). More recent work, however, has addressed two important (and yet unanswered) questions (e.g., Basinger and Hallerberg 2004; Devereau et al 2008; Hays 2003; 2009; Swank 2006). First, these studies theorize and test competing, complex models of strategic interdependence between nations. At a minimum, most recent work allows for some type of spatial policy diffusion as nations respond to policy change in other political economies (e.g., Franseze and Hays 2008). Some scholars go beyond simple diffusion models and argue that competitor nations strategically act on the basis of recent

\footnotetext{
${ }^{1}$ Given the assumption of durable democratic institutions and issues of data availability,
} the sample consists of 18 nations: Australia, Austria, Belgium, Canada, Denmark, Finland, France, Germany, Ireland, Italy, Japan, Netherlands, New Zealand, Norway, Sweden, Switzerland, the United Kingdom, and the United States. 
political and economic signals and simultaneously set tax rates on mobile assets in a Nash competitive game (e.g., Basinger and Hallerberg 2004); I have argued that both theory and the empirical record point to the predominate role of the 1980s first move of the United States, the world's dominant economy, and the subsequent competitive responses of other nations (Swank 2006). I provide a comparative assessment of these and alternative models of tax competition below.

Second, recent studies raise the issue of how domestic institutions matter to the pace and depth of tax policy change. For instance, Hays $(2003 ; 2009)$ has stressed that the historically low taxes of capital-poor consensus democracies actually allow policy makers in these polities to respond to contemporary capital mobility with increases in taxes on mobile assets. Others have emphasized that the degrees to which the median voter has shifted right on redistribution and right-of-center parties have governed in recent years should be consequential for tax policy change (Basinger and Hallerberg 2004; Plümper, Troeger, and Winner 2009; Swank, 2006). In addition, the strength of coordinated market institutions should significantly condition the pace of neoliberal reforms (Swank 2006; 2008). ${ }^{2}$

I organize my analysis as follows. First, after commenting on recent tax trends, I more fully outline and juxtapose theories about tax competition and domestic institutional impacts on policy change. I then develop empirical models of corporate tax rates and assess these with 1982to-2008 data from 18 nations. As most published work rarely extends far into the twenty-first

${ }^{2}$ This paper significantly elaborates the theory in Swank $(2006 ; 2008)$ that the institutions of coordinated economies fundamentally shape the pace of neoliberal reforms, and tests the relative importance of coordination and other institutional factors. 
century, an extension of analyses of tax competition and domestic institutions to 2008 is important: continued internationalization, political and institutional change, and significant tax reforms from the late 1990s to 2008 in several nations call for new analysis. ${ }^{3}$ I conclude with some reflections about the future of tax policy and the broader spread of neoliberalism and institutional change in advanced democratic capitalism.

\section{Corporate Tax Policy Change, Tax Competition, and Domestic Institutions}

Since the early 1980s, the structure of relatively high statutory rates and extensive use of tax instruments to target investment was significantly altered in virtually all nations. Figure 1 documents the secular trend (see Note 1 on included nations). Policy makers reduced statutory corporate tax rates on average from 49 percent in 1982 to 28 percent in 2010 . Yet, the crossnational variability of corporate statutory rates (as measured by the coefficient of variation) did not decline; if anything it has slightly increased. An initial up-tick in variability occurs in the late 1980s (temporally corresponding to the differential responses to U.S. tax reforms), and the modestly higher variability is sustained to the present. Most notably, the early 1980s "high-tax equilibrium" is largely replaced by a "low-tax equilibrium" in the $2000 \mathrm{~s}^{4}$

${ }^{3}$ I do not take the analysis past 2008 because data are unavailable for some institutional dimensions in recent years. Also, the global financial crisis and attendant recession create dramatic oscillations in economic forces and generate special short-term tax policy measures. These factors complicate drawing general inferences. I do offer, however, observations drawn from the paper's analyses on post-2008 trajectories of tax policy in the conclusions.

${ }^{4}$ Policy makers also eliminated or reduced various tax allowances that had lowered effective corporate tax rates on less profitable enterprises and on reinvested profits (e.g., Boskin 


\section{— Figure 1 about here -}

At the same time, the pace and depth of policy reform varies across nations. Some nations (the Anglo democracies and the Netherlands) cut statutory rates relatively quickly (and concomitantly reduced or eliminated tax-based investment incentives); this generally occurred in the mid- to late 1980s. Many other countries acted in the early 1990s (the Nordic and most continental European nations). For a few polities (Italy and Japan), significant market-oriented tax reforms did not occur until the late 1990s or early 2000's. ${ }^{5}$ What roles do international integration, tax competition, and domestic institutions play in this transformation of tax policy?

\section{Globalization, Tax Competition, and Policy Change}

The "globalization thesis" of tax policy change has been a prominent focus of extensive research. The common version of this argument suggests that the capacity of mobile asset holders to move investment across national borders forces incumbent governments (regardless of ideology or constituency) to compete for investment. Taxes on capital (and generally mobile, high income earners) are progressively lowered while tax burdens on relatively immobile factors and McClure 1990; Ganghof 2000; Genschel 1999). Effective average tax rates on profitable corporations - rates that differ only modestly from statutory rates - were reduced from 42 to 30 percent between 1982 and 2005. Rates on less profitable enterprises declined from 34 to 25 percent during the same period.

${ }^{5}$ It is also important to observe that despite notable cuts in statutory tax rates, governments collected on average roughly 30 percent of capital income in revenue in 1982 and in 2008. The sources of this stability have been addressed elsewhere (Swank and Steinmo 2002; Plümper, Troeger, and Winner 2009) and, for practical reasons, are not directly analyzed here. 
and activities (i.e., most labor and consumption) are raised. The majority of "first generation" studies on tax competition, in fact, report a negative association between general levels of trade openness and capital mobility on the one hand, and statutory and effective corporate tax rates on the other (Leibrecht and Hochgatterer 2012; Genschel and Schwartz 2011).

Strategic Interdependence: The United States as Stackelberg Leader. Recent work on tax policy makes clear incumbent governments not only respond to commonly experienced pressures from international openness (the most rudimentary type of tax competition), they are also likely to take leads from policy change in competitor nations (e.g., Basinger and Hallerberg 2004; Hayes 2003; Swank 2006). ${ }^{6}$ One highly plausible form of strategic tax competition is that of competitive national responses to the first move of a Stackelberg leader; the United States is the primary candidate to play this role. ${ }^{7}$ As I argued in earlier work (Swank 2006; 2008), the catalyst of contemporary tax policy reform is the U.S. 1986 Tax Reform Act: top statutory corporate rates were cut over several years from 46 to 34 percent, the investment tax credit was suspended,

${ }^{6}$ Simmons, Dobbin, and Garrett (2006) note that the diffusion of neoliberal policies may also occur through coercion, rational learning, and social emulation. In Swank (2006; 2008), however, I find little evidence of these other forms of diffusion. For some new evidence on tax policy learning, see Jensen and Linstädt 2012.

${ }^{7}$ A Stackelberg leader is formally a large, dominant economy that is a net lender of capital; I use the term more loosely to designate a large, dominant economy whose domestic markets and international flows are so large as to shape economic policy and performance in the pool of similarly situated economies. Also see Kumar and Quinn (2012) on the U.S. as a global Stackelberg leader in tax reform. 
and accelerated depreciation and a variety of other allowances were reduced.

The potential international impacts of 1986 Act were quickly evident. Enacted in the context of convergence in policy-maker thinking about taxation and motivated by common concerns over economic stagnation, the reform "sent shock waves to other countries" (Tanzi 1987, p. 335). Tanzi, in fact, cites a variety of OECD, IMF, and country-specific sources to illustrate that in the wake of the U.S. reforms, policy makers in most advanced democracies became deeply worried that lower marginal rates may result in a "capital drain" of mobile investment to the United States. ${ }^{8}$ Other analysts agree that policy makers in most nations quickly appreciated that significant reductions in the statutory corporate rate increase the intake of foreign direct investment and retain the income from that investment in the low-tax jurisdiction by reducing the incentive to shift earnings to other nations through transfer pricing (Boskin and McClure 1990; Pechman 1988). As scholars also note, the international impacts of corporate tax rate reduction should be especially large if initiated by countries such as the U.S. whose supply of foreign capital and domestic markets are very important for many countries. ${ }^{9}$ Ganghof and Eccelston (2004) argue that these dynamics clearly contribute to the significant downward movement in corporate rates in other nations after the U.S. tax reforms.

Nash Games of Competitive Strategic Interdependence. Basinger and Hallerberg (2004)

${ }^{8}$ Britain reduced corporate rates in 1984; Ireland cut corporate tax rates in 1981. Several other nations had enacted modest neoliberal reforms (e.g., Boskin and McClure 1990; Peckman 1988; Tanzi 1987). However, the large majority of nations had yet to act in 1986.

${ }^{9}$ For instance, the United States accounted for between 40 and 50 percent of all FDI and portfolio capital inflows at the beginning of the $21^{\text {st }}$ Century (IMF 1998). 
have offered what is arguably the most plausible alternative to the Stackelberg model. They propose a Nash-type game of strategic interaction where tax reforms of nations are chosen simultaneously. Significant uncertainty exists with regard to other nations' likely tax reforms (and for the likelihood that reforms will be rewarded by capital investment). Each nation's effort at tax reform is determined by domestic political and economic costs; these take the form of constituency costs (e.g., citizen backlash over perceived attacks on fairness) and political transactions costs such as those generated by negotiations over policy reform among ideological distinct governing partners. Economic payoffs for tax cuts are affected by transactions costs on capital movements such as those created by capital controls.

At the same time, national policy makers must simultaneously weigh tax reform effort in other nations. They monitor competitors with respect to constituency and political transactions costs as well as constraints on capital mobility. Shifts in the ideological position of the incumbent government (or more fundamentally the median voter), declines in ideological distance among government coalition parties, and liberalization of capital controls all signal reduced friction in tax policy reform effort in competitor nations. The game is played and policy makers adapt positions based on payoffs and new conditions. I will assess below the Basinger and Hallerberg model, the Stackelberg model, and other types of tax competition.

\section{Politics, Institutions, and the Spread of Neoliberal Tax Reform}

Political institutions should directly shape the pace and depth of tax policy change. Institutions should also condition policy-maker responsiveness to international pressures. I assess three types of models of domestic political institutional mediation of international tax competition. First, Hays $(2003 ; 2009)$ argues that consensus democratic institutions in relatively 
small and capital-poor polities - democracies characterized by proportional representation, many effective parliamentary parties, oversized cabinets and related characteristics of Lijphart's (2012) executives/parties dimension of consensus democracy - have traditionally enacted low levels of capital taxation. This is so because business parties are guaranteed representation by consensus institutions and because dramatic redistributions of income possible in majoritarian systems by a single-party government of workers are eschewed in consensus democratic contexts (also see Hertel-Fernandez and Martin 2014). Hays theorizes that with capital mobility, (typically capital rich) majoritarian polities will reduce tax rates while consensus democracies may have room (given extant, low tax rates) to increase capital tax rates to achieve optimal revenue-raising tax levels.

The second model, prefigured in earlier discussion, stresses direct and mediating roles of politics, namely, the political transactions costs of policy reform created by fragmented institutions and the constituency costs of (neoliberal) policy change generated by egalitarian ideological forces. Hallerberg and Basinger (1998) have argued that multiparty legislatures and cabinets and horizontally and vertically fragmented political authority (i.e., partisan and institutional veto points) create opportunities for opponents to slow or block policy change. In addition, as noted above, Basinger and Hallerberg (2004) and Swank (2006; 2008) have argued that constraints on policy change are created by domestic "constituency costs" such as ideological resistance of electorates to market-oriented reforms. Relatedly, Plümper, Troeger, and Winner (2009) stress that societal fairness norms (for instance, public support for redistribution) will constrain the reduction of tax burdens on corporations and capital income. Thus, I account for the direct tax policy effects of consensus institutions (partisan veto points), 
institutional veto points, and constituency costs; I also assess whether or not these factors mediate pressures from international tax competition.

Varieties of Democratic Capitalism. Third, in my preferred model of tax competition and democratic institutions (and, here, I significantly extend the argument made in Swank [2006; 2008]), I assume that all policy makers seek to maximize - subject to political economic and institutional constraints - economic performance and political support. In the short term, incumbent governments will also strive to maintain revenue levels to fund preferred programs as well as limit public deficits and debt. Left and Christian Democratic governments, however, have different intermediate and long-term targets for the level and distribution of taxes than center and, especially, right parties. Ultimately, the likelihood of a shift to neoliberal tax policy should be a function of the relative weights assigned by policy makers to the expected political and economic benefits and costs associated with neoliberal tax structure. These assessments, and the ultimate decision to adopt or not adopt neoliberal reforms, should be, in turn, influenced by the foundational institutions of the political economy, namely, the degree to which markets are coordinated by employers, labor and the state.

To streamline a complex argument, one can imagine a Samuelson-type rule for optimal policy change: tax rate reductions will proceed until $M B_{\text {POLECON }}=M C_{\text {POLECON, }}$ where $M B$ and $M C$ refer, respectively, to marginal political and economic benefits and costs of policy reform. In this highly stylized model of policy choice, $M B_{\text {POLECON }}$ and $M C_{\text {POLECON }}$ are given by the following:

$$
\begin{aligned}
& M B_{\text {POLECON }}=b_{1}\left(\sum I N V E S T\right)+b_{2}\left(\sum S U P P O R T\right) \\
& M C_{\text {POLECON }}=\tau_{1}\left(\sum \text { CONSTITUENT }\right)+\tau_{2}\left(\sum \text { TRANSACT }\right)+\tau_{3}\left(\sum I N E F F I C I E N C Y\right),
\end{aligned}
$$


where, $\sum I N V E S T$ is the sum across all households of the income and employment gains from greater capital investment and $\Sigma S U P P O R T$ is the sum across all households of the increase in vote support and government performance approval (that flow, for instance, from credit-claiming by incumbents). $\sum$ CONSTITUENT is the sum of negative ideological/normative effects across households of tax reforms, $\sum T R A N S A C T$ is the societal sum of political costs of negotiating change, and EINEFFICIENCY is the sum across households of negative economic effects of neoliberal reforms (as explained below). The parameters $b_{1}$ and $b_{2}$ are decreasing functions of coordination of markets and the parameters $\tau_{1}, \tau_{2}$, and $\tau_{3}$ are increasing functions of coordination.

To elaborate, countries may be classified by the extent to which employers (labor and the state) develop institutions of coordination in the face of firms' control, information, and collective action problems in purely competitive markets (e.g., Hall and Soskice 2001). Labor and industrial relations are addressed through national or sectoral collective bargaining among relatively well-organized employer and labor associations. Labor-management relations within the firm are organized by works councils and other cooperative enterprise arrangements. Collective business goods problems (e.g., training, R\&D) are addressed through enterprise consortiums and other cooperative firm associations. Close coordination of finance and producers through bank finance and cross-holding (as opposed to equity markets) foster longterm development (i.e., incremental innovation) of high quality, diversified products. Coordination of economic activity by business is supported by stable long-run labor-business relations and by complementary state regulation.

Traditionally interventionist tax policy - the "high tax equilibrium" of high rates and extensive investment allowances - has played two key roles in coordinated economies. First, it 
has facilitated state promotion of long-run growth through regional and sector targeting of investment during economic modernization and restructuring. In the Nordic countries, for instance, high statutory rates on uninvested profits coupled with general investment reserves and targeted investment incentives complemented other supply-side policies (credit and active labor market policy) in promoting smooth business cycle adjustment and high employment (Huber and Stephens 1998). Second, tax policies of high statutory capital tax rates (and high employer social insurance contributions) have been instrumental to the maintenance of labor's acceptance of ownership and managerial prerogatives, general social solidarity, and long-term stability in labor and industrial relations (Swank 2002, Ch. 5).

Given these considerations, the costs and benefits of neoliberal tax reform across varieties of capitalism is clear. In terms of costs, policy makers in coordinated market economies (hereafter CMEs) face potentially high constituency costs with neoliberal reform as citizens commonly display more collectivist and pro-redistributive attitudes than those in liberal market economies (hereafter LMEs). For instance, the simple bivariate correlation between support for redistribution by the median voter and coordination across the 18 focal nations in 2008 is .43 , p < .05. (See Appendix on measurement and data sources.) Political transactions costs are also high; CMEs are characterized by consensus institutions that foster inclusiveness of societal interests and diffuse power across multiparty legislatures and cabinets (e.g., Lijphart 2012; Martin and Swank 2012). CMEs are also characterized by extensive national and sectoral delegation of policy making power to employers and labor. As such, national policy makers in CMEs typically face an array of bipartite and tripartite forums that accord opportunities for opponents to block policy change. 
Neoliberal policy reform may also create inefficiencies in CMEs. As Hall and Soskice (2001) and Hall and Gingerich (2009) have argued, elements of national economic models are functionally interdependent. Fundamental reforms in one area have significant potential impacts on the performance of other features of the model. More concretely, business, labor, and the state have interests in the maintenance of the core elements of the country's predominant model (Soskice 1999). For instance, as Thelen (1999) demonstrates for Germany for the relevant timeframe of reform, German employer support for maintenance of basic features of coordination and the policies they entail was arguably rooted in the interests of business in promoting long-term stability in the labor and industrial relations system. These interests are grounded in the fact that producers in CMEs rely on stable production to maintain share in highly competitive international markets for high-end products (also see Martin and Swank 2012, esp. Ch. 11). Generally, the greater the coordination of the economy, the higher the economic uncertainty to policy makers from adoption of the market-conforming tax paradigm.

With respect to benefits of neoliberal tax policy, the potential for economic performancebased gains in votes and incumbent public approval in CMEs is more limited than in LMEs. This is so because, as noted, CMEs have consensus-based institutions as opposed to majoritarian institutions. And, as extensive research on economic determinants on votes and approval has shown, consensus institutions such as multiparty cabinets blur macroeconomic policy responsibility and, hence, blunt the strength of economic effects on the vote and approval ratings (see the synoptic survey in Lewis-Beck and Stegmaier 2008). With regard to economic benefits of tax policy reform, CMEs (as LMEs) enjoy potential income and employment gains from capital inflows. Yet, while formal capital controls have largely been abolished in the CMEs, 
several core features of the CME model may be in tension with global market-driven allocation of capital that is fostered by tax competition. For instance, significant formal and informal impediments to mergers and takeovers, continued reliance on long-term bank finance, and other persistent features of coordination certainly mitigate some of potential market efficiency effects of successful tax competition in CMEs (that are expected to materialize in LMEs). ${ }^{10}$

In sum, I expect the parameters capturing political and economic benefits of neoliberal tax reform to decrease with coordination; those parameters that gauge political (constituency and transactions) and economic costs of reform should increase with coordination. With respect to concrete hypotheses, one way in which CME institutions mediate tax competition is through the operation of consensus political institutions that are associated with CMEs; another set of mechanisms involves the greater level of support for collectivist and egalitarian policies associated with CME structures. As such, the CME hypothesis is consistent with - indeed subsumes - the consensus and median voter hypotheses. A final set of mediating mechanisms consists of the complementarities among CME institutions and their bias (discussed above) toward non-market activities, policies, and practices. As such, we should expect the level of coordination to mediate tax competition in general, and in the presence of significant mediation of international competition by consensus institutions or by left-leaning voters.

\section{Empirical Models of Tax Policy Reform}

${ }^{10}$ Research has shown, for instance, reforms that introduce or extend short-term market forces in one area (e.g., capital markets) while coordination persists in another (e.g., labor and industrial relations) may result in lower economic growth (e.g., Hall and Gingerich 2009; Martin and Swank 2012). 
I draw on Swank and Steinmo (2002) and Swank (2006) to develop tests of hypotheses on neoliberal reform, tax competition and domestic institutions. In this work, tax rates were modeled as a function of international capital mobility and trade openness, domestic economic pressures (e.g., long-term unemployment), and public sector debt as well as business cycle dynamics (economic growth, profits, and investment), partisan control of government, and prior levels of tax rates. Swank and Steinmo (2002) estimated the models with 1981-1995 data for 14 developed democracies; Swank $(2006 ; 2008)$ extended the analysis to the 1982-to-1998 period and incorporated policy interdependence by assessing diffusion processes.

In the present paper, I extend the sample a full decade - to 2008 - and use data from 18 advanced nations; the theoretical and substantive scope of the paper is expanded to include new tests of tax competition and domestic politics and institutions not considered in earlier work. I focus primarily on statutory corporate tax rates: statutory corporate tax rates are a direct indicator of policy, closely proxy the structural change in corporate taxation, and are the most visible sign of nations' tax burdens on corporate income. Statutory corporate rates are also strongly correlated (.90 or greater for the current sample) with effective average tax rates on highly profitable enterprises; investment from these corporations should be the focus of much international tax competition. ${ }^{11}$

${ }^{11}$ I estimate, below, the final model of corporate tax burdens with a measure of effective average corporate tax rates as a key test of the robustness of core findings. In the Online Appendix (see http://www.marquette.edu/polisci/faculty_swank.shtml), I offer other tests of model robustness and generalizability. Indicators of effective average corporate rates are used as secondary measures of corporate taxation as they are available for fewer country years and are computed 
A basic linear model of corporate tax rates is given by:

$$
\begin{aligned}
& \text { Tax Rate }_{i, t}=\alpha+\varphi(\text { Tax Rate })_{i, t-1}+\beta_{l}(\text { International Capital Mobility })_{i, t-1}+\quad \text { [Eq. 1] } \\
& \beta_{2}(\text { Trade Openness })_{i, t-1}+\beta_{3}(\text { Coordination })_{i, t-1} \\
& +\beta_{4}(\text { Consensus Institutions/Partisan Veto Points })_{i, t-1}+\beta_{5}(\text { Institutional Veto } \\
& \text { Points })_{i, t-1}+\beta_{6}(\text { Median Voter })_{i, t-1}+\beta 7(\text { Right Party Government })_{i, t-1}+ \\
& \beta_{8}(\text { Structural Unemployment })_{i, t-1}+\beta_{9}(\text { Public Debt })_{i, t}+\beta_{10}(\text { Growth })_{i, t-l}+ \\
& \beta_{11}(\text { Profits })_{i, t-1}+\beta_{12}(\text { Investment })_{i, t-1}+\varepsilon_{i, t},
\end{aligned}
$$

This model includes the basic exogenous factors discussed above; it also accounts for core institutional variables. I use a standard-score index of coordination across four core dimensions, namely, collective bargaining, enterprise-level labor-management relations, finance-producer relations, and firm organization for collective business goods. (See the Appendix, below, on measurement and data sources for all variables.) In addition, I include institutional veto points (a standard score index of federalism, bicameralism, separation of powers, and judicial review), and I use two indicators of partisan veto points; a measure of the parties-executives dimension of consensus democracy (standard score index of electoral proportionality, the number of effective legislative parties, and the number of governing parties) and a measure of the maximum ideological distance between governing parties (Tsebelis 1999). For domestic constituency costs (and constituency costs in competitor nations), I use primarily the Kim-Fording (1998; 2003) measure of the ideological position of the median voter. ${ }^{12}$ with a variety of assumptions about corporate behavior and economic performance.

${ }^{12}$ I also substitute related, alternative measures for the left-right orientation of the median voter such as median voter support for redistribution (see results in the Online Appendix). 
The basic model of Eq. 1 assumes independence in national responses, or that the shift to a market-conforming tax model is a function of varying national responses to common domestic and international forces; policy makers may respond to perceived competitive pressures associated with higher trade and capital openness, but they do so independently of specific policy choices in other nations. We want, however, to allow for and assess the role of alternative forms of strategic interdependence among governments. Thus, I test the proposition that policy makers monitored and responded to the first move of the globe's dominant economy (that is, the Stackelberg leader):

$$
\begin{aligned}
& \operatorname{Tax}_{\text {Rate }_{i, t}}=\alpha+\varphi(\text { Tax Rate })_{i, t-1}+\varphi_{u s}(\text { U.S. Tax Rate })_{i, t-1}+\quad \text { [Eq. 2] } \\
& \beta_{1}(\text { International Capital Mobility })_{i, t-1}+\ldots \ldots \ldots \ldots \\
& \beta_{12}(\text { Investment })_{i, t-1}+\varepsilon_{i, t},
\end{aligned}
$$

where $\varphi_{u s}$ captures the effect of U.S. reforms in corporate taxation in other nations.

To test Basinger and Hallerberg's Nash model of strategic interdependence, I estimate the effect of competition-weighted shifts in the ideological position of the median voter ("constituency costs" of tax reform), the degree of ideological distance among governing parties ("transactions costs" of tax reform), and the liberalization of capital controls in other nations. Thus, a straightforward empirical model for the Nash game of strategic interdependence is:

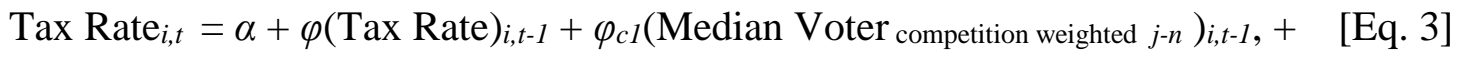

$$
\begin{aligned}
& \varphi_{c 2}(\text { Ideological Distance competition weighted } j-n) i, t-1,+ \\
& \varphi_{c 3}(\text { Capital Liberalization competition weighted } j-n) i, t-1, \\
& \beta_{1}(\text { International Capital Mobility })_{i, t-1}+\ldots \ldots \ldots \ldots \beta_{12}(\text { Investment })_{i, t-1}+\varepsilon_{i, t}
\end{aligned}
$$

where these three signals of tax reform effort in each of $j-n$ countries are weighted by the 
correlation at $t$ - $l$ between some country's pattern of trade and the focal country's $(i)$ pattern of trade. The pattern-of-trade variable for any country at $t-1$ is the inflow and outflow of merchandise trade relative to GDP for the nation and each of the other (17) developed capitalist democracies. Thus, if say Sweden and Denmark's pattern of trade at some time point, $t-1$, is correlated at .93, the weight for the signal of policy reform effort in Sweden at $t-1$, if the point of interest is tax policy in Denmark at time $t$, is .93. The variable, (Tax Reform Effort Signal competition weighted $j-n)_{i, t-1}$, is the mean of these weighted lag signals of reform effort for countries $j$ $n .^{13}$ That is, for some time $t-1$ and country $i$, where $s$ is the signal of tax reform effort in the competitor and $w$ is the pattern-of-trade-correlation weight, the weighted signal of tax reform effort is: $\left(\mathrm{w}_{\mathrm{ij}} \mathrm{S}_{\mathrm{j}}+\mathrm{w}_{\mathrm{ik}} \mathrm{S}_{\mathrm{k}} \ldots .+\mathrm{w}_{\mathrm{in}} \mathrm{S}_{\mathrm{n}}\right) /\left(\mathrm{w}_{\mathrm{ij}}+\mathrm{w}_{\mathrm{ik}} \ldots .+\mathrm{w}_{\mathrm{in}}\right)$

After tests of tax competition hypotheses, I focus on the possibility that tax competition is mediated by domestic institutions. First, I address Hays' (2003; 2009) argument by examining whether capital mobility's impacts are conditioned by consensus institutions. I then assess whether tax competition (for instance, pressures from prior US rate change) is mediated by coordination as well as other domestic political and institutional conditions (the magnitude of transactions costs and so forth). These tests are made through interaction analysis (Kam and

${ }^{13}$ It is important to note that the use of bilateral trade data also effectively proxies bilateral capital stock and flow relations between two nations. For instance, the simple crossnational correlation between trade with the US and capital stock position with the U.S. (19891991 means) is .689 ( $\mathrm{p}<.01)$ for OECD nations. The highly significant correlations for bilateral trade and capital flows for any pair of economies at $t$ time points range from roughly .5 to .98 for nations in the sample. 
Franzese 2009).

It is also important to mention three specification issues. First, statutory rates at time $t$ invariably reflect policy decisions at time $t-1$. Even for those instances where rates at time $t$ are the product of earlier, multi-year policy choices, policy makers ratify or modify those rate changes in $t$ - 1 . Thus, when examining forms of Nash strategic interdependence, one has to examine other nations' signals of likely change in tax effort at $t-1$. In the Stackelberg model, the leader moves first (i.e., in $t-1$ ). Second, I assume that current changes in statutory rates in some country are not significant predictors of past levels and changes in U.S. rates or in signals of tax reform effort in competitors. That is, I assume endogeneity should not be a serious problem. (In results reported in the Online Appendix, I do estimate a conventional spatial lag model where current changes in rates are modeled as functions of current changes in competitors; there, I use an instrumental variable model in the presence of a real threat of endogeneity.)

Third, for theoretical and substantive reasons it is very useful to assess both long-term relationships and short-term departures from equilibrium engendered by tax competition and other forces; thus, I use an error correction mechanism (ECM) specification for the actual estimation of the basic models of corporate tax rates. The estimating equation, therefore, takes the following form (and I use the Stackelberg leadership model for illustration):

$$
\begin{gathered}
\Delta \text { Tax Rate }_{i, t}=\alpha+\varphi(\text { Tax Rate })_{i, t-1}+\varphi_{u s}(\text { U.S. Tax Rate })_{i, t-2}+ \\
\varphi_{u s \Delta}(\Delta \text { U.S. Tax Rate })_{i, t-1}+\beta_{1}(\text { International Capital Mobility })_{i, t-2}+ \\
\beta_{1 \Delta}(\Delta \text { International Capital Mobility })_{i, t-1}+\ldots \ldots \ldots \ldots . . . \\
\beta_{12}(\text { Investment })_{i, t-2}+\beta_{12 \Delta}(\Delta \text { Investment })_{i, t-1} \quad \varepsilon_{i, t},
\end{gathered}
$$

ECM models operate on the assumption that the dependent variable (statutory corporate rates) is 
in general equilibrium with domestic and international political economic conditions. A change in an exogenous variable produces a short-term impact on the dependent variable; if that change is permanent, there is a long-term shift in the dependent variable toward a new equilibrium level.

In a concrete sense, changes in statutory tax rates are modeled as a function of past levels of tax rates and changes and levels of exogenous variables. The coefficient for change in some causal factor is the short-term effect of that variable on statutory rates while the coefficient for levels is the long-run impact of that variable on rates. The actual long-term impact of some exogenous variable is, $-\beta / \varphi$, where $\beta$ is the estimated coefficient for the level of the causal variable and $\varphi$ is the coefficient for lagged statutory tax rates (see Beck [2001] and, especially, Beck [1991] on this estimator). ${ }^{14}$ I follow Beck (1991) and estimate the ECM model with one year lags in changes and two-year lags in levels. This is a reasonable alternative to the conventional unlagged changes and one-year lagged levels when clear time lags are present.

The error correction models are estimated by OLS regression analysis with panel correct standard errors. Overall, this estimator will typically address common problems of contemporaneously correlated, crossnationally heteroskedastic, and serially correlated errors present in pooled time series, cross sectional data (Beck 2001). To minimize the risks of bias

14 Thus, as Huber (1998) suggests, calculation of the long-term effect of exogenous factors in ERM models proceeds as it does in standard lagged dependent variable models. The long-term effect unfolds over several periods with the speed of adjustment given by $\varphi$. That is, the gap between the old and new equilibrium levels in the dependent variable decreases by the proportion, $\varphi$, in each period. 
from omitted cross-national variables, I also estimate core models with fixed country effects. ${ }^{15}$

I also explore an additional set of tax competition hypotheses and assess the impacts of additional control variables. For instance, I test a more basic formulation of strategic interdependence by estimating the effect of competition- weighted tax rates themselves (that is, a conventional spatial lag model). I also assess the impact of East European states' tax reforms (for instance, the widespread adoption of the flat tax) on rich European nations' corporate tax rates. As to further controls, I estimate models with a variety of additional variables, most notably, population size and capital flows (in place of liberalization of capital controls). These and other tests are reported in the Online Appendix.

\section{Findings}

Results of the estimation of the basic model of corporate tax rates (without strategic interaction) are presented in the first column of Table 1. The tax effects of commonly experienced international forces are as follows. The level of (and changes in) trade openness and liberalization of international capital controls in prior years are significantly associated with reductions in statutory corporate rates. The substantive effects of shifts in the levels of trade and capital openness are substantial: a 10 point increase in trade openness (exports and imports as percentages of GDP) results in a 2.83 decrease in statutory rates (recall that the long-term impact of a variable is given by, $-\beta / \varphi)$. A five point rise in Quinn's index of capital liberalization $(0.0$ to 100 scale) results in a 2.6 point decline in rates. Taken together, these findings suggest that

\footnotetext{
${ }^{15}$ F-tests suggest inclusion of fixed country effects. The presence of these "country dummies," however, risks inconsistency of estimates as $t$ grows relatively small in relation to $n$; this should be a minimal problem relative to bias in models such as those estimated here.
} 
rises in internationalization engender long-term reductions in corporate tax rates as policy makers seek mobile assets and general efficiency gains.

\section{- Table 1 about here -}

The second through fourth columns of Table 1 report results of tests of competing models of strategic tax competition. First, the Stackelberg leadership model of column two indicates that U.S. corporate tax reforms have elicited significant policy changes in other developed democracies: a one point cut in levels of U.S. rates results in a 1.1 point cut in levels of tax rates in other nations. A short-term change in U.S. rates of one point also generates an immediate change in corporate rates in other countries (of the magnitude of .37 points); the remainder of the 1.1 point gap between old and new long-term equilibrium levels of corporate rates will decline by a proportion of .244 a year. This long-term impact of U.S. rate change will play itself out in about six years.

The column three model also generates support (albeit weak) for the Nash game of strategic competition among competitors. As levels of capital control liberalization increase in competitor nations by five points, a typical nation will reduce rates by 2.64 points in the long term. On the other hand, shifts in the levels or changes in partisan veto points and median voter ideology in competitors have insignificant or incorrectly signed impacts on statutory corporate tax rates.

Finally, I assess a mixed Stackelberg-Nash model in the fourth column of Table 1. I include only the significant capital control liberalization signal of tax reform effort in competitors. The results are the same if I include the insignificant partisan veto points or incorrectly signed median voter variables. As the table indicates, once U.S. tax reforms are 
accounted, the effect on statutory rates of capital control liberalization in competitor nations is only marginally significant. Moreover, this effect disappears in some subsequent models. As a result, I use the highly robust Stackelberg leadership model as the baseline for analyses of the impacts of U.S. tax reform across divergent domestic political and institutional contexts below.

With respect to domestic forces, (levels of) the ideological position of the median voter (0.0 to 100 point scale where higher scores denote more collectivist orientations) and the extent of institutional veto points directly constrained tax policy change (see Table 2 for more evidence on the strength of institutional veto points). Where median voters lean left and where power is institutionally dispersed, corporate tax burdens do not fall as quickly as in polities with concentrated authority and with right-leaning voters. On the other hand, partisan veto points (as measured by either consensus democracy or ideological distance between governing parties) and right government did not directly shape tax reform. With respect to coordination, the direct effect of the level of coordination is significant in the majority of Table 1 and 2 equations. With regard to domestic fiscal and economic forces, higher public sector debt constrains and slower profit growth promotes neoliberal tax reforms. For instance, the long-term impact of an additional 10 points of public debt (percentage points of GDP) on statutory rates is +1.3 . Overall, the findings on domestic constituency and transactions costs as well as fiscal constraints are robust across subsequent models of corporate tax policy.

\section{- Table 2 about here -}

I present the results of estimation of models of politically and institutionally mediated tax competition in Table 2. The column one model assesses whether the general corporate tax rate impact of capital control liberalization is mediated by consensus institutions (as suggested by 
Hays 2003; 2009). Columns two and three present tests of the hypotheses that domestic political transactions and constituency costs condition the impact of tax competition (in the form of Stackelberg leadership effects of U.S. tax policy). As the table reveals, the interaction between (levels or changes in) capital control liberalization and consensus institutions is insignificant. On the other hand, when actual capital flows is substituted for capital control liberalization, the interaction between levels of capital openness and consensus democracy is significant and positive. The actual magnitude of coefficients for the direct effect of capital flows (-.018) and the interaction (.030) indicate that at moderately high levels of consensus democracy (index values of greater than .5), the negative effect of capital flows on statutory rates disappears. (See Note 19 below on the mathematics of interactions.) Overall, this pattern of findings as well as subsequent findings on the salience of consensus institutions in Table 2 suggests at least a modicum of support for Hays' thesis. ${ }^{16}$

With respect to the institutional mediation of pressures from tax competition, both consensus democracy and the ideological position of the median voter mediate competitive pressures from recent changes in U.S. tax rates. In the case of both political factors, changes in U.S. rates have diminishing and, eventually, insignificant effects on statutory rates; that is, a cut in U.S. rates engenders rate cuts in majoritarian polities and where the median voter leans right, but these impacts dissipate when we move to consensus democracies and more collectivist electorates (see Note 19 on interactions). ${ }^{17}$

16 I report the full results for key models that substitute capital flows for capital liberalization in the Online Appendix.

${ }^{17}$ In addition to the institutional mediation of U.S. reforms, I assessed the institutional 
The fourth column presents a test of my central argument that where the institutions of economic coordination are strong, neoliberal tax effects of international competitive pressures should be weak or non-existent. As the table reveals, there is a significant (and substantively large) negative interaction between changes in U.S. rates and coordination (short-term effects). There is a significant (but substantively small) positive interaction between levels of U.S. tax rates and coordination (long-term effects), although a shift in levels of U.S. rates is associated positively with levels of statutory rates in all types of political economies. ${ }^{18}$

On the short term effects of U.S. reforms across levels of coordination, the mathematics of interactions suggest that an additional cut of one point in U.S. statutory rates is associated with mediation of capital mobility and trade openness' impacts on rates. Beyond consensus institutions and the median voter, I also included (as a second measure of partisan veto points) the maximum ideological distance between governing parties as well as institutional veto points as possible mediating factors. These tests produced largely null findings, incorrectly signed coefficients, and/or non-robust results.

18 That is, neoliberal reforms in the U.S. produce neoliberal reforms in all types of polities in the long-run. The positive interaction between levels of U.S. rates and coordination, a finding that suggests greater long-term change in response to U.S. reforms in CMEs, might be questioned because of very high levels of multicollinearity between levels of U.S. rates and interaction terms that include these levels and institutional factors. (High levels of multicollinearity are defined as those where " $\mathrm{R}^{2}$-deletes" are in excess of .85 ; an $\mathrm{R}^{2}$-delete is the multiple correlation coefficient obtained by regressing a right-hand side variable on all other exogenous variables.) 
immediate cuts of .75 in tax rates in a set of typical LMEs, as theory predicts; changes in U.S. rates are insignificantly related to short-term changes in statutory rates in a set of typical CMEs. ${ }^{19}$ Figure 2 displays the marginal short-term tax rate effects of a one point cut in U.S. statutory rates for various levels of coordination. At relatively high levels of coordination (.9 or higher on the index of coordination), the otherwise strong impact of U.S. tax reforms disappears completely.

\section{- Figure 2 about here -}

Taken together, these results suggest the following: in the long-term, all advanced capitalist democracies move with the U.S. in adopting the market-conforming tax regime. In the short-term, however, there is substantial resistance to neoliberal tax reforms in CMEs. In fact, estimates of corporate tax rate change from these models fit the empirical record well: in most CMEs, adoption of the neoliberal tax structure of lower rates and broader bases occurs a few years after initial moves by U.S. policy makers (e.g., in the early 1990s); LMEs followed the U.S. immediately with tax reforms in the late 1980s. In the end, however, all political economies moved to the structure of lower statutory rates and broader tax bases.

${ }^{19}$ Recall that the effect of some variable $\mathrm{X}_{1}$ on $\mathrm{Y}$ at variable levels of $\mathrm{X}_{2}$ is given by $\beta_{1}+$ $\beta_{3}\left[X_{2}\right]$, where $\beta_{3}$ is the coefficient for the interaction of $X_{1}$ and $X_{2}$. Standard errors for these marginal effects are readily computed (Kam and Franzese 2009). For the short-term impacts of changes in U.S. rates, the equations for CMEs and LMEs are, respectively: .04121 + (-.3119[.9]) $=.1314 ;$ and $.4121+(-.3119[-1.11])=.7552)$, where .90 is the mean $1980-1983$ level of coordination in the CME proto-types Austria, Norway, and Sweden and -1.11 is the 1980-1983 mean coordination in the LME countries of Australia, New Zealand, and the United Kingdom. 
The fifth and sixth columns of Table 2 address the question of whether or not coordination, consensus democracy, and the ideological position of the median voter all independently mediate tax competition's impact on tax reform. That is, theory suggests coordination's mediating role occurs through the operation of associated consensus institutions and collective-oriented median voter dynamics as well as through direct mechanisms. An alternative view is that coordination only matters because it is related to consensus democracy and left-leaning voters. I offer suggestive evidence in the fifth and sixth columns of Table 2. I say "suggestive" because levels of multicollinearity are high for several components of the two sets of interactions in each column; sign-flips and insignificance of coefficients may occur (Kam and Franzese 2009). The inclusion of three sets of interactions heightens multicollinearity even further and, thus, is not used.

As Table 2 reveals, the core mediation effect of coordination is robust to inclusion of either consensus democracy or median voter ideology. In addition, both of these variables continue to play a significant role in mediating international tax competition (although the shape of the mediating role changes a bit with multiple sets of interactions). While coordination and median voter ideology both act to mitigate the short-run impacts of U.S. tax reforms, consensus institutions appear to weaken the long-term effect of neoliberal tax policy. Overall, these findings provide some support for the argument that non-market coordination and its political institutional correlates significantly condition international competition's impacts on tax policy change in postindustrial capitalist democracies.

As a core test of the robustness of findings, I estimate the "final" model of statutory corporate tax rates for the effective average tax rate on "high profit" corporations (40 percent 
rate of return). As revealed in Table 2, the institutional mediation of tax competition (in the form of Stackelberg dynamics mediated by coordination) is reproduced for high profit enterprises' effective average tax rates. So too are the findings that institutional veto points, left-leaning median voters, and profit rates directly shape tax policy change. The only notable differences between statutory and effective average tax rate models is, first, that the fiscal health of the polity is no longer a significant constraint on reform of effective rates on high profit enterprises.

Second, economic growth independently influences effective corporate tax rates. Finally, the direct impacts of trade and capital openness fall below conventional significance levels in the effective rate model of the final column of Table 2. Generally, these results along with those reported in the Online Appendix suggest most core findings are robust to a variety of alternative specifications and estimations.

\section{Conclusions}

During the past two decades, the tax treatment of corporate income has changed dramatically across the capitalist democracies. While the pace and depth of change is different across nations and time periods, corporate tax rates have been reduced and the tax bases broadened through reductions in investment credits and allowances in virtually all countries. In fact, not only have instruments and the settings of those instruments been altered, but the basic goals of tax policy have seemingly shifted from redistribution and interventionism toward efficiency (Swank and Steinmo 2002; Swank 2006). What role has tax competition played in the transformation of corporate taxation and what form has it taken? How have domestic institutions shaped competition's policy impacts?

The findings presented in this paper offer new insights on these questions, and they 
affirm some earlier results for a larger sample of country years and of more dimensions of tax competition, political institutions, and their interactions. The transformation of corporate tax policy was shaped by the responsiveness of incumbent governments to common international and domestic pressures. Increases in international integration of markets for goods, services and capital militated toward adoption of market-conforming tax structure; the room for maneuver by policy makers, however, was in all likelihood constrained by domestic constituency, transactions, and fiscal costs. That is, I find substantial evidence that left-leaning voters, the institutional dispersion of power, and levels of public debt directly constrained neoliberal reforms; declines in profit rates promoted tax cuts.

The shift to neoliberal tax structure was, however, by no means solely a response by national policy makers to these commonly experienced forces. The transformation of corporate tax policy was driven, in part, by strategic tax competition between nations. While several alternative forms of tax competition are plausible, analysis presented here strongly points to the role of competitive responses to the 1980s tax reform in the United States. Moreover, there is clear and robust evidence that domestic institutions and politics condition the speed of policy responsiveness to the Stackelberg leader; findings strongly suggest that the degree a nation is characterized by coordinated market institutions - centralized collective bargaining between well organized labor and employers, high levels of cooperation by private firms in provision of collective business goods and stable finance, and related institutions and their political correlates - determines the speed at which the U.S. inspired reforms are adapted. In LMEs, the perceived relative political and economic benefits of following the United States offset the (relatively low) costs of negotiating change across resistant voters and veto points and of economic uncertainty. 
These costs were clearly more pronounced in CMEs and the benefits to policy makers of neoliberal reforms smaller and less certain. Nevertheless, in the long run, all nations moved in the direction of the United States; indeed, as the first decade of the $21^{\text {st }}$ Century drew to a close, the neoliberal structure of corporate taxation had spread throughout the rich capitalist democracies.

It is also important to note that the recent global financial crisis and attendant great recession have not in all likelihood initiated a long-term reversal of this process. On the one hand, this paper's analysis suggests that the recent growth in public sector debt in many advanced democracies has placed upward pressure on corporate rates since 2008. On the other, the resilience of neoliberalism at elite and mass levels (Schmidt and Thatcher 2013), the decline of coordination in some nations (Martin and Swank 2012; Thelen 2014), and further pressure on the U.S. to reduce its post-1980s statutory rate suggest continued movement toward lower rates and market-conforming tax structure. The principal offsetting force consists of ongoing efforts between all advanced democracies, and especially among members of the European Union, to bolster tax coordination. The difficulties of cooperation on tax policy, however, among generally competitive states of different size are significant (Genschel and Schwarz 2011).

Finally, one might reflect on the implications of this analysis for the spread of neoliberal institutions and the broader transformation of advanced democratic capitalism. Some scholars have argued that core features of coordinated capitalism such as highly centralized labor and industrial relations systems have significantly liberalized (e.g., Baccaro and Howell 2011). Others have argued that while many of the formal institutions of CMEs have not undergone significant neoliberal reform, informal practices and outcomes have increasingly resembled less 
egalitarian and less cooperative LMEs (e.g., Thelen 2014). In fact, Wolfgang Streek (2009) offers a systematic analysis of institutional change in Germany and concludes that most institutional spheres - from labor and institutional relations to social policy - have effectively liberalized. The present analysis of tax policy sheds some light on underlying dynamics of institutional change and on the dilemma facing proponents of coordinated market institutions. First, the theory and empirical evidence of the present paper argues that neoliberal policies and institutions spread slowly in the environment of coordinated market economies. The assessment of political and economic benefits and costs by policy makers in coordinated systems and their pursuant choices clearly explain this inertia. Yet, the present work suggests as coordinated institutions and attendant policies and practices erode in the long term, the political economic calculus that buffers CMEs from rapid reform will shift in the favor of neoliberalism; if one can generalize from tax policy, this shift has been going on for some time. Yet, final conclusions about convergence around conventional neoliberal institutions in advanced democratic capitalism await more evidence on national trajectories in the wake of the financial crisis, on the emergence of potentially dominant postindustrial political coalitions, and on new, alternative forms and mixes of political economic institutions.

\section{APPENDIX}

\section{Operationalization and Data Sources}

Statutory and Effective Average Corporate Tax Rates: See text. Sources: For statutory rates, OECD Taxation Database. For effective and marginal corporate rates, Institute of Fiscal Studies; on computation of rates see Devereux, Griffith, and Klemm (2002). 
International Capital Mobility: Index of the liberalization of financial and capital controls developed by Quinn (1997) where liberalization is a 0.0 to 100.0 mean scale of the removal of capital controls and restrictions on current account transactions. Source: data from Dennis Quinn, Graduate School of Business, Georgetown University.

Trade Openness: exports and imports as percentages of GDP. Source: components from OECD iLibrary.

Bilateral Trade Flows: exports and imports of merchandise (as a percentage of GDP) between nation $i$ and nation $j$ at $t$. Source: International Monetary Fund, Direction of Trade Statistics Yearbook (Paris: IMF, selected years).

Right Government: Percentage of cabinet portfolios held by Right parties (mean of one-to-threeyear lags). Source: Comparative Parties Data Set, available at (http://www.marquette.edu/polisci/faculty_swank.shtml).

Coordination. See text. For extensive details on measurement and data sources for employer and union organization, see Swank (2014). On finance producer relations, labor-management relations, and cooperation for collective business goods, see online appendix for Martin and Swank (2012): http://www.cambridge.org/us/academic/subjects/politicsinternational-relations/comparative-politics/political-construction-business-interestscoordination-growth-and-equality.

Median Voter: Ideological position of median voters as developed by Kim and Fording (1998; 2003), where median voter position is computed from vote shares for ideologically ranked parties (28-item index of a parties' positions on traditional left-right continuum) through the application of the formula for the median in grouped data. The Kim-Fording 
measure of voter ideology (1945-2003 data) supplied by HeeMin Kim, Florida State University. Updates computed from European Journal of Political Research "Political Data" reports on annual elections and Party Manifesto Data Base data on ideological positions of parties (Volkens, et al 2014).

Support for Redistribution: I follow Plümper, Troeger, and Winner (2009) and measure support for redistribution as the median (and mean) scores of citizens' reponses to the statement: "It is the responsibility of the government to reduce the differences in income between people with high incomes and those with low incomes" (1.0-5.0 ordinal scale of supportopposition). Source: International Social Survey Programm (Role of Government, Social Inequality series). Second, I use the pre-fisc GINI index of inequality and changes between pre- and post-fisc GINIs as proxies for demands/support for redistribution. Source: OECD Inequality Data Set, OECD iLibrary.

Institutional Veto Points: Standard score index for temporally and cross-nationally varying measures of federalism/decentralization, bicameralism, presidentialism, and judicial review. Source: Lijphart (2012) and country specific sources.

Consensus Democracy: standard score index of proportionality of electoral system, number of effective legislative parties; number of governing parties. Source: computations following procedures outlined in Lijphart (2012) where data are from Thomas Mackie and Richard Rose, International Almanac of Electoral History (Macmillan, 1991); "Political Data" updates in European Journal of Political Research (selected years).

Partisan Veto Points: maximum ideological distance among government parties; Kim-Fording measure of party ideology. Source: 1945-2003 data supplied by HeeMin Kim, 
Department of Political Science, Florida State University. Updates computed from European Journal of Political Research "Political Data" reports on annual elections in developed democracies and Party Manifesto Data Base data on ideological positions of parties.

Structural Unemployment: the percentage of the civilian labor force unemployed for one year or more. Source: OECD iLibrary.

Profits: Percentage change in real operating surplus. Source: OECD iLibrary.

Investment: Percentage change in gross fixed capital accumulation. Source: OECD iLibrary.

Growth: Percentage change in real per capita GDP. Source: Penn World Table Version 7.0, Center for International Comparisons of Production.

Public Sector Debt: Gross public debt as a percent of GDP. Source: OECD iLibrary. 
Author Biographical Note: Duane Swank is Professor of Political Science at Marquette University and President of the American Political Science Association Organized Section in Comparative Politics. He is the author of Global Capital, Political Institutions, and Policy Change in Developed Welfare States (Cambridge University Press 2002) and, with Cathie Jo Martin, The Political Construction of Business Interests (Cambridge 2012).

Address for Correspondence: Duane Swank, Professor, Department of Political Science, Marquette University, PO Box 1881, Milwaukee, WI 53201-1881; email:

Duane.swank@marquette.edu.

Acknowledgments: I thank Dennis Quinn for access to unpublished data on capital market liberalization and Mujtaba Ali Isani, Molly Giese, and Darren Nah for excellent research assistance. I also thank John Freeman, Dennis Quinn, and David Rueda as well as participants on multiple panels at Annual Meetings of the Midwest and American Political Science Associations and at the 2007 Nuffield College Political Economy Colloquium, Oxford University, for comments on work directly feeding into this paper. 


\section{REFERENCES}

Baccaro, L. and Howell, C. (2011) 'A common neoliberal trajectory: the transformation of industrial relations in advanced capitalism', Politics and Society 39 (4): 521-63.

Basinger, S. and Hallerberg, M. (2004) 'Remodeling the competition for capital: how domestic politics erases the race to the bottom', American Political Science Review 98 (2):261-276.

Beck, N. (1991) 'Comparing dynamic specifications: the case of presidential approval', Political Analysis 3: 51-87.

Beck, N. (2001) 'Time-series — cross-section data: what we have learned in the past few years', American Review of Political Science 4: 271-93.

Boskin, Ml. and McLure, C. (eds.) (1990) World Tax Reform: Case Studies of Developed and Developing Countries, San Francisco, ICS Press.

Devereux, M.P., Griffith, R. and Klemm, A. (2002) 'Corporate income tax reforms and international tax competition', Economic Policy 17 (35): 452-495.

Devereux, M. P., Lockwood, B. and Redoano, M. (2008) 'Do countries compete over corporate tax rates', Journal of Public Economics 92 (5-6): 1210-1235.

Franzese, R. and Hays, J. (2007) 'Interdependence in comparative politics: substance, theory, empirics, substance', Comparative Political Studies 41 (4/5): $742-78$

Ganghof, S. (2000) 'Adjusting national tax policy to economic internationalization: strategies and outcomes', in F. Scharpf and V. Schmidt (eds.), Welfare and Work in the Open Economy Volume II: Diverse Responses to Common Challenges, Oxford: Oxford University Press, pp. 597—645.

Ganghof, S. (2004) 'Progressive income taxation in advanced OECD countries: revisiting the 
structural dependence of the state on capital', paper presented at the $100^{\text {th }}$ Annual Meeting of the American Political Science Association, September, Chicago.

Ganghof, S. and Eccelston, R. (2004) 'Globalization and the dilemma of income taxation in Australia', Australian Journal of Political Science 39 (3):519-534.

Genschel, P. (1999) 'Tax competition and the welfare state', typescript, Max Planck Institute for the Study of Societies, Cologne, Germany.

Genschel, P. and Schwarz, P. (2011) 'Tax competition: a literature review', Socio-Economic Review 9 (2): 339-70.

Hall, P. and Soskice, D. (eds.) (2001) Varieties of Capitalism: The Institutional Foundations of Comparative Advantage, New York: Oxford University Press.

Hall, P. and Gingerich, D. (2009) 'Varieties of capitalism and institutional complementarities in the political economy: an empirical analysis', British Journal of Political Science 39 (3): 449-482.

Hallerberg, M. and Basinger, S. (1998) 'Internationalization and changes in tax policy in OECD countries: the importance of domestic veto players', Comparative Political Studies 31 (3): 321-353.

Hays, J. (2003) 'Globalization and capital taxation in consensus and majoritarian democracies', World Politics 56 (1): 79-113.

Hays, J. (2009) Globalization and the New Politics of Embedded Liberalism, New York: Oxford University Press.

Hertel-Fernandez, A. and Martin, C. J. (2014) 'How employers and conservatives shaped the modern tax state', typescript, Department of Political Science, Boston University. 
Huber, J. D. (1998) 'How does cabinet instability affect political performance? Portfolio volatility and health care cost containment in parliamentary democracies', American Political Science Review 92 (3): 577-91.

Huber, E. and Stephens, J. D. (1998) 'Internationalization and the social democratic welfare model: crises and future prospects', Comparative Political Studies 33 (3): 353-397.

International Monetary Fund (1998) Balance of Trade Statistics, 1998, Washington, DC: IMF.

Jensen, N. and René Lindstädt, R. (2012) 'Leaning right and learning from the left: diffusion of corporate tax policy across borders', Comparative Political Studies 45 (3): 283-311.

Kam, C. D. and Franzese. R. (2009) Modeling and Interpreting Interactive Hypotheses in Regression Analysis, Ann Arbor: University of Michigan Press.

Kim, H. and Fording, R. C. (1998) 'Voter Ideology in Western Democracies, 1946-1989', European Journal of Political Research 33 (1): 73-97

Kim, H. and Fording, R. C. (2003) 'Voter Ideology in Western Democracies: An Update', European Journal of Political Research 42 (1): 95-105

Kumar, M. S. and Quinn, D. P. (2012) 'Globalization and corporate taxation’, IMF Working Paper WP/12/252, Fiscal Affairs and Finance Department, October.

Leibrecht, M. and Hochgatterer, C. (2012) 'Tax competition as a cause of falling corporate income tax rates: a survey of empirical literature', Journal of Economic Surveys 26 (4): 616-48.

Lewis-Beck, M. and Stegmaier, M. (2007) 'Economic models of voting', in R. J. Dalton and H.D. Klingemann, Oxford Handbook of Political Behavior, New York: Oxford University Press, pp. 518-537. 
Lijphart, A. (2012) Patterns of Democracy: Government Forms and Performance in Thirty-Six Countires $2^{\text {nd }}$ Edition, New Haven: Yale University Press.

Martin, C. J. and Swank, D. (2012) The Political Construction of Business Interests: Coordination, Growth, and Equality, New York: Cambridge University Press.

Pechman, J. A. (ed.) (1988) World Tax Reform: A Progress Report. Washington, D.C., The Brookings Institution.

Plümper, T., Troeger, V. and Winner, H. (2009) 'Why is there no race to the bottom in capital taxation?', International Studies Quarterly 53 (3): 761-86.

Quinn, D. 1997. 'The Correlates of Change in International Financial Regulation', American Political Science Review 91 (2):531-552.

Schmidt, V. and Thatcher, M. (2013) Resilient Liberalism in Europe's Political Economy, Oxford: Oxford University Press.

Simmons, B., Dobbin, F. and Garrett, G. (eds.) (2008) The Global Diffusion of Markets and Democracy, New York: Cambridge University Press.

Soskice, D. (1999) 'Divergent production regimes: coordinated and uncoordinated market economies in the 1980s and 1990s, in edited by Herbert Kitschelt, Peter Lange, Gary Marks, and John Stephens, Continuity and Change in Contemporary Capitalism, New York: Cambridge University Press, pp. 101-134.

Streeck, W. (2009) Re-Forming Capitalism: Institutional Change in the German Political Economy. New York: Oxford University Press.

Swank, D. (2002) Global Capital, Political Institutions, and Policy Change in Developed Welfare States, New York: Cambridge University Press. 
Swank, D. (2006) 'Tax policy in the era of internationalization: explaining the spread of neoliberalism', International Organization 60 (4): 847-82.

Swank, D. (2008) 'Tax policy in the era of internationalization: as assessment of a conditional diffusion model of the spread of neoliberalism', in B. A. Simmons, F. Dobbin, and G. Garrett (eds.), The Global Diffusion of Markets and Democracy, New York: Cambridge University Press, pp. 64-103.

Swank, D. (2014) 'The Political Sources of Labor Market Dualism in Post-industrial Democracies', Review of Keynesian Economics 2 (2): 234-57.

Swank, D. and Steinmo, S. (2002) 'The new political economy of taxation in advanced capitalist democracies', American Journal of Political Science 46 (3): 642-55.

Tanzi, V. (1987) 'The response of other industrial countries to the U.S.Tax Reform Act', National Tax Journal 40 (3): 339-355.

Thelen, K. (1999) 'Why German employers cannot bring themselves to dismantle the German model." in edited by Torben Iversen, Jonas Pontusson, and Davod Soskice (eds), Unions, Employers, and Central Banks, New York: Cambridge University Press, pp. 138-172.

Thelen, K. (2014) Varieties of Liberalization and the New Politics of Social Solidarity, New York: Cambridge University Press.

Tsebelis, G. (1999) 'Veto players and law production in parliamentary democracy." American Political Science Review 93 (3): 591-608.

Volkens, A., Lehmann, P., Merz, N., Regel, S. Werner, A. with Schultze, H. (2014) The Manifesto Data Colletion. Manifesto Project (MRG/CMP/MARPOR). Version 2014b, Berlin: Wissenschaftzentrum Berlin für Sozialforschung (WZB). 
Table 1: The Impact of International Competition on Statutory Tax Rates on Corporate Income, 1982-2008,

\begin{tabular}{cccc}
\hline $\begin{array}{c}\text { Globalization- Policy } \\
\text { Independence }\end{array}$ & Stackelberg Leadership & $\begin{array}{c}\text { Nash Strategic } \\
\text { Interdependence }\end{array}$ & $\begin{array}{c}\text { Mixed Model } \\
\text { Stackelberg-Nash }\end{array}$ \\
\hline
\end{tabular}

\section{Tax Competition}

US Statutory

Corporate Rate t-2 $_{2}$

$\Delta$ US Statutory

Corporate Tax Rate t-1 $_{1}$

Partisan Veto Power

in Competitors $\mathrm{t}-2_{2}$

$\Delta$ Partisan Veto Power

Competitors $_{\mathrm{t}-1}$

Ideology of Median

Voter Competitors ${ }_{\mathrm{t}-2}$

$\Delta$ Ideology of Median

Voter Competitors ${ }_{t-1}$

Capital Controls in

Competitors ${ }_{t-2}$

$\Delta$ Capital Controls in

Competitors $_{\mathrm{t}-1}$

International Openness

Trade Openness $\mathrm{t}_{\mathrm{t}-2}$

$\Delta$ Trade Openness ${ }_{\mathrm{t}-1}$

Liberalization of

Capital Markets t-2

$\Delta$ Liberalization of

Capital Markets ${ }_{\mathrm{t}-1}$

Institutions and Politics

Coordination $_{\mathrm{t}-2}$

$\Delta$ Coordination $_{\mathrm{t}-1}$

Consensus Demo ${ }_{t-2}$

$\Delta$ Consensus Demo ${ }_{\mathrm{t}-1}$

Institutional Veto

Points $t_{-2}$

$\Delta$ Institutional Veto

Points $_{\mathrm{t}-1}$

$\begin{array}{cc} & .2659 * * \\ -- & (.0481 \\ & \\ --- & .3721 * * \\ & (.0898\end{array}$

$.1751^{* *}$

481)

(.0763)

$.3459 * *$

(.0949)

-0623

$---1.0506)$

.0547

$(.0549)$

$-.0467$

(.0434)

$-.2203 * *$

$(.1060)$

$-.1287 * *$

$(.0352)$

$-.0723 *$

(.0493)

$-.1601 * *$

$-.1000$

$(.0915)$

(.1019)

$$
\begin{array}{r}
-.0486 * * \\
(.0201) \\
-.0577 * \\
(.0374) \\
-.0892 * *
\end{array}
$$

$-.0787 * *$

$(.0180)$

$-.0470 * *$

(.0186)

$-.0731 * *$

(.0188)

$-.0360$

(.0323)

$-.0449 *$

(.0329)

$-.0382$

(.0324)

-.0590 **

$-.0742 * *$

(.0172)

$-.0590 * *$

(.0181)

$-.0446 *$

(.0304)

$-.0260$

$-.0253$

(.0301)

$1.8400^{* * *}$

(.9299)

.6667

(.9365)

$1.7803^{* *} *$

(.8746)

$-.0640$

$-1.1377$

(.9205)

$-1.4029$

(1.5739)

(1.6066)

(.15493)

$-.1206$

(1.5882)

.5691

(.5676)

.6111

$.7621 *$

(.5774)

(.5785)

.9353

(.5886)

1.0694

(.8521)

(.8533)

(.8817)

(.8539)

$3.2067 * *$

1.2518

3.0511**

(1.2327)

$-.0863$

(1.2392)

1.5784

$2.8321^{*}$

(1.9162) 


\author{
Ideology -Median \\ Voter $_{\mathrm{t}-2}$ \\ $\Delta$ Ideology -Median \\ Voter $_{\mathrm{t}-1}$ \\ Right Government \\ $\mathrm{t}-4$ to $\mathrm{t}-2$ \\ $\Delta$ Right Government \\ $\mathrm{t}-4$ to $\mathrm{t}-2$
}

\section{General Model}

Structural

Unemployment $\mathrm{t}-2$

$\triangle$ Structural

Unemployment $t-1$

Public Sector Debt ${ }_{\mathrm{t}-2}$

$\triangle$ Public Sector

Debt $_{\text {t-1 }}$

Percent Change Real

Profits $_{\mathrm{t}-2}$

$\Delta$ Percent Change

Real Profits t-1

Domestic

Investment $_{\mathrm{t}-2}$

$\Delta$ Domestic

Investment $_{\mathrm{t}-1}$

Growth Per Capita

Real GDP ${ }_{t-2}$

$\triangle$ Growth Per Capita

Real GDP ${ }_{\mathrm{t}-1}(\times 100)$

Tax Rate $_{\mathrm{t}-1}$

Fixed Effects

Constant

Observations

$\mathrm{R}^{2}$

\begin{tabular}{crrr}
\hline $\begin{array}{c}\text { Globalization- Policy } \\
\text { Independence }\end{array}$ & Stackelberg Leadership & $\begin{array}{c}\text { Nash Strategic } \\
\text { Interdependence }\end{array}$ & $\begin{array}{c}\text { Mixed Model } \\
\text { Stackelberg-Nash }\end{array}$ \\
\hline $.0264 *$ & $.0327 * *$ & $.0314 * *$ \\
$.0192)$ & $(.0173)$ & $(.0172)$ & $.0250^{*}$ \\
.0062 & .0391 & .0308 & .0377 \\
$(.0395)$ & $(.0378)$ & $(.0376)$ & $(.0380)$ \\
-.0004 & .0021 & -.0018 & .0016 \\
$(.0035)$ & $(.0039)$ & $(.0032)$ & $(.0039)$ \\
.0133 & .0118 & .0099 & .0104 \\
$(.0086)$ & $(.0094)$ & $(.0082)$ & $(.0093)$
\end{tabular}

\begin{tabular}{|c|c|c|c|}
\hline $\begin{array}{c}-.0333 * \\
(.0201)\end{array}$ & $\begin{array}{r}-.0127 \\
(.0202)\end{array}$ & $\begin{array}{r}-.0365^{* *} \\
(.0206)\end{array}$ & $\begin{array}{r}-.0165 \\
(.0264)\end{array}$ \\
\hline $\begin{array}{r}-.0324 \\
(.0356)\end{array}$ & $\begin{array}{r}-.0390 \\
(.0337)\end{array}$ & $\begin{array}{c}-.0455^{*} \\
(.0339)\end{array}$ & $\begin{array}{r}-.0404 \\
(.0339)\end{array}$ \\
\hline $\begin{array}{c}.0228 * * \\
(.0100)\end{array}$ & $\begin{array}{r}.0311^{* * *} \\
(.0109)\end{array}$ & $\begin{array}{c}.0304 * * \\
(.0110)\end{array}$ & $\begin{array}{r}.0328 * * \\
(.0113)\end{array}$ \\
\hline $\begin{array}{c}.0985 * * \\
(.0400)\end{array}$ & $\begin{array}{r}.0511 \\
(.0410)\end{array}$ & $\begin{array}{r}.0676 * * \\
(.0391)\end{array}$ & $\begin{array}{r}.0520 \\
(.0410)\end{array}$ \\
\hline $\begin{array}{c}.0947 * \\
(.0584)\end{array}$ & $\begin{array}{r}.0567 \\
(.0570)\end{array}$ & $\begin{array}{r}.0661 \\
(.0568)\end{array}$ & $\begin{array}{r}.0572 \\
(.0574)\end{array}$ \\
\hline $\begin{array}{l}.0606 * \\
(.0425)\end{array}$ & $\begin{array}{l}.0531 * \\
(.0414)\end{array}$ & $\begin{array}{r}.0424 \\
(.0408)\end{array}$ & $\begin{array}{c}.0540^{*} \\
(.0415)\end{array}$ \\
\hline $\begin{array}{r}.0375 \\
(.0439)\end{array}$ & $\begin{array}{r}.0122 \\
(.0433)\end{array}$ & $\begin{array}{r}.0244 \\
(.0431)\end{array}$ & $\begin{array}{r}.0090 \\
(.0435)\end{array}$ \\
\hline $\begin{array}{r}-.0053 \\
(.0257)\end{array}$ & $\begin{array}{r}-.0162 \\
(.0296)\end{array}$ & $\begin{array}{r}-.0124 \\
(.0284)\end{array}$ & $\begin{array}{r}-.0136 \\
(.0294)\end{array}$ \\
\hline $\begin{array}{r}.0755 \\
(.1431)\end{array}$ & $\begin{array}{r}.1606 \\
(.1427)\end{array}$ & $\begin{array}{r}.0995 \\
(.1421)\end{array}$ & $\begin{array}{r}.1765 \\
(.1436)\end{array}$ \\
\hline $\begin{array}{r}-.0028 \\
(.0034)\end{array}$ & $\begin{array}{r}-.0008 \\
(.0032)\end{array}$ & $\begin{array}{r}-.0001 \\
(.0035)\end{array}$ & $\begin{array}{c}-.0005 \\
(.0033)\end{array}$ \\
\hline $\begin{array}{r}-.1715^{* * *} \\
(.0286)\end{array}$ & $\begin{array}{r}-.2440 * * \\
(.0340)\end{array}$ & $\begin{array}{r}-.2445^{* *} \\
(.0362)\end{array}$ & $\begin{array}{r}-.2532 * * \\
(.0361)\end{array}$ \\
\hline Yes & Yes & Yes & Yes \\
\hline 12.3744 & 8.0039 & 30.0561 & 19.0609 \\
\hline 497 & 469 & 497 & 469 \\
\hline .1612 & .2233 & .2115 & .2271 \\
\hline
\end{tabular}

Statutory corporate tax models are estimated with 1982-2008 data by OLS for 18 or 17 nations (full sample with or without U.S.) The table reports OLS unstandardized regression coefficients and panel correct standard errors (Beck and Katz 1996).

* indicates significance at the .10 level or below.

** indicates significance at the .05 level or below. 
Table 2: Domestic Institutions and International Competition in Corporate Income Tax Rates, 1982-2008.

\begin{tabular}{|c|c|c|c|c|c|c|c|}
\hline & $\begin{array}{l}\text { Capital } \\
\text { Mobility - } \\
\text { Consensus } \\
\text { Democracy }\end{array}$ & $\begin{array}{l}\text { US Leadership- } \\
\text { Consensus } \\
\text { Democracy }\end{array}$ & $\begin{array}{l}\text { US Leadership- } \\
\text { Median Voter }\end{array}$ & $\begin{array}{l}\text { CMEs versus } \\
\text { LMEs }\end{array}$ & $\begin{array}{l}\text { US Leadership- } \\
\text { Consensus and } \\
\text { Coordination }\end{array}$ & $\begin{array}{c}\text { US } \\
\text { Leadership- } \\
\text { Median Vote } \\
\text { and Coord }\end{array}$ & $\begin{array}{c}\text { Effective } \\
\text { Corporate Tax } \\
\text { Rates }\end{array}$ \\
\hline \multicolumn{8}{|l|}{ Competition and Institutions } \\
\hline $\begin{array}{l}\text { US Statutory/Effective } \\
\text { Corporate Tax Rate }_{\mathrm{t}-2}\end{array}$ & $\begin{array}{r}.2172 * * \\
(.0482)\end{array}$ & $\begin{array}{r}.2695^{* *} \\
(.0477)\end{array}$ & $\begin{array}{l}-.1396 \\
(.1801)\end{array}$ & $\begin{array}{r}.2608 * * \\
(.0482)\end{array}$ & $\begin{array}{r}.2516^{* *} \\
(.0477)\end{array}$ & $\begin{array}{l}-.0471 \\
(.1954)\end{array}$ & $\begin{array}{r}.4876 * * \\
(.0852)\end{array}$ \\
\hline $\begin{array}{l}\Delta \text { US Statutory/Effective } \\
\text { Corporate Tax Rate }{ }_{t-1}\end{array}$ & $\begin{array}{r}.3735^{* *} \\
(.0902)\end{array}$ & $\begin{array}{r}.3706^{* * *} \\
(.0896)\end{array}$ & $\begin{array}{r}1.6044 * * \\
(.4473)\end{array}$ & $\begin{array}{r}.4121^{* *} \\
(.0887)\end{array}$ & $\begin{array}{r}.4043^{* *} \\
(.0878)\end{array}$ & $\begin{array}{r}1.2906 * * \\
(.5132)\end{array}$ & $\begin{array}{r}.2200 * * \\
(.1041)\end{array}$ \\
\hline $\begin{array}{l}\text { Capital Liberalization } \times \\
\text { Consensus Democracy } \mathrm{t}_{\mathrm{t}-2}\end{array}$ & $\begin{array}{r}.0024 \\
(.0151)\end{array}$ & --- & --- & --- & --- & --- & --- \\
\hline $\begin{array}{l}\Delta \text { Capital Liberalization } \times \\
\text { Consensus Democracy }{ }_{t-2}\end{array}$ & $\begin{array}{r}.0085 \\
(.0346)\end{array}$ & --- & --- & --- & --- & --- & --- \\
\hline $\begin{array}{l}\text { US Statutory Rate } \times \\
\text { Consensus Democracy }{ }_{t-2}\end{array}$ & --- & $\begin{array}{r}-.0030 \\
(.0312)\end{array}$ & --- & --- & $\begin{array}{r}-.0927 * * \\
(.0299)\end{array}$ & --- & --- \\
\hline $\begin{array}{l}\Delta \text { US Statutory Rate } \times \\
\text { Consensus Democracy }{ }_{\mathrm{t}-2}\end{array}$ & --- & $\begin{array}{r}-.2564 * * \\
(.0818)\end{array}$ & --- & --- & $\begin{array}{r}-.1251^{* *} \\
(.0687)\end{array}$ & --- & --- \\
\hline $\begin{array}{l}\text { US Statutory Rate } \times \\
\text { Median Voter }_{\text {t-2 }}\end{array}$ & --- & --- & $\begin{array}{r}.0079 * * \\
(.0032)\end{array}$ & -- & --- & $\begin{array}{r}.0060^{* *} \\
(.0036)\end{array}$ & --- \\
\hline $\begin{array}{l}\Delta \text { US Statutory Rate } \times \\
\text { Median Voter }{ }_{t-2}\end{array}$ & --- & --- & $\begin{array}{r}-.0229 * * \\
(.0082)\end{array}$ & --- & --- & $\begin{array}{r}-.0166^{* *} \\
(.0095)\end{array}$ & --- \\
\hline $\begin{array}{l}\text { US Stat/Effect Rate } \times \\
\text { Coordination }_{\mathrm{t}-2}\end{array}$ & --- & --- & --- & $\begin{array}{r}.1152 * * \\
(.0442)\end{array}$ & $\begin{array}{r}.1746^{* *} \\
(.0479)\end{array}$ & $\begin{array}{r}.0834 * * \\
(.0468)\end{array}$ & $\begin{array}{r}.0907 * * \\
(.0567)\end{array}$ \\
\hline $\begin{array}{l}\Delta \text { US Stat/Effect Rate } \times \\
\text { Coordination } \\
\mathrm{t}-2\end{array}$ & --- & --- & --- & $\begin{array}{r}-.3119 * * \\
(.0909)\end{array}$ & $\begin{array}{r}-.2448 * * \\
(.0860)\end{array}$ & $\begin{array}{r}-.2263 * * \\
(.1072)\end{array}$ & $\begin{array}{r}-.1764 * * \\
(.0867)\end{array}$ \\
\hline \multicolumn{8}{|l|}{ International Openness } \\
\hline Trade Openness $_{t-2}$ & $\begin{array}{r}-.0789 * * \\
(.0182)\end{array}$ & $\begin{array}{r}-.0794 * * \\
(.0181)\end{array}$ & $\begin{array}{r}-.0951 * * \\
(.0184)\end{array}$ & $\begin{array}{r}-.0884 * * \\
(.0180)\end{array}$ & $\begin{array}{r}-.0939 * * \\
(.0187)\end{array}$ & $\begin{array}{r}-.0640 * * \\
(.0317)\end{array}$ & $\begin{array}{r}-.0231 \\
(.0228)\end{array}$ \\
\hline$\Delta$ Trade Openness $\mathrm{t}-1_{1}$ & $\begin{array}{l}-.0354 \\
(.0326)\end{array}$ & $\begin{array}{l}-.0412 \\
(.0324)\end{array}$ & $\begin{array}{r}-.0605 * * \\
(.0321)\end{array}$ & $\begin{array}{r}-.0493 * * \\
(.0317)\end{array}$ & $\begin{array}{c}-.0521^{*} \\
(.0319)\end{array}$ & $\begin{array}{r}-.0640 * * \\
(.0317)\end{array}$ & $\begin{array}{r}-.0429 \\
(.0587)\end{array}$ \\
\hline
\end{tabular}




\begin{tabular}{|c|c|c|c|c|c|c|c|}
\hline $\begin{array}{l}\text { Liberalization of } \\
\text { Capital Markets } t-2\end{array}$ & $\begin{array}{r}-.0594 * * \\
(.0194)\end{array}$ & $\begin{array}{r}-.0534 * * \\
(.0192)\end{array}$ & $\begin{array}{r}-.0348 * * \\
(.0197)\end{array}$ & $\begin{array}{r}-.0493 * * \\
(.0186)\end{array}$ & $\begin{array}{r}-.0534 * * \\
(.0185)\end{array}$ & $\begin{array}{r}-.0339 * * \\
(.0191)\end{array}$ & $\begin{aligned}-.0230 \\
(.0237)\end{aligned}$ \\
\hline $\begin{array}{l}\Delta \text { Liberalization of } \\
\text { Capital Markets } \\
\mathrm{t}-1\end{array}$ & $\begin{array}{l}-.0267 \\
(.0310)\end{array}$ & $\begin{array}{r}-.0288 \\
(.0298)\end{array}$ & $\begin{array}{r}-.0122 \\
(.0298)\end{array}$ & $\begin{array}{l}-.0144 \\
(.0291)\end{array}$ & $\begin{array}{l}-.0178 \\
(.0290)\end{array}$ & $\begin{array}{l}-.0073 \\
(.0292)\end{array}$ & $\begin{array}{r}.0846^{* * *} \\
(.0422)\end{array}$ \\
\hline \multicolumn{8}{|l|}{ Institutions and Politics } \\
\hline Coordination $_{\mathrm{t}-2}$ & $\begin{array}{r}1.8820 * * \\
(.9475)\end{array}$ & $\begin{array}{r}1.7080 * * \\
(.9614)\end{array}$ & $\begin{array}{r}1.3001 * \\
(.8322)\end{array}$ & $\begin{array}{r}-4.9352^{*} \\
(2.7929)\end{array}$ & $\begin{array}{r}-7.4143 * * \\
(2.8900)\end{array}$ & $\begin{array}{r}-3.4740 \\
(2.8560)\end{array}$ & $\begin{array}{r}1.0184 \\
(3.1279)\end{array}$ \\
\hline$\Delta$ Coordination $_{\mathrm{t}-1}$ & $\begin{array}{r}-.0324 \\
(1.6067)\end{array}$ & $\begin{array}{r}-.1226 \\
(1.5909)\end{array}$ & $\begin{array}{r}-.5472 \\
(1.5522)\end{array}$ & $\begin{array}{l}-1.3828 \\
(1.5784)\end{array}$ & $\begin{array}{r}-1.2731 \\
(1.5667)\end{array}$ & $\begin{array}{r}-1.3798 \\
(1.591\end{array}$ & $\begin{array}{r}1.7735 \\
(2.1658)\end{array}$ \\
\hline Consensus Demo ${ }_{\mathrm{t}-2}$ & $\begin{array}{r}.3660 \\
(1.4454)\end{array}$ & $\begin{array}{r}.5034 \\
(1.4802)\end{array}$ & $\begin{array}{r}.4871 \\
(.5374)\end{array}$ & $\begin{array}{r}.3751 \\
(.5376)\end{array}$ & $\begin{array}{r}4.2167 * * \\
(1.3926)\end{array}$ & $\begin{array}{r}.3659 \\
(.5201)\end{array}$ & $\begin{array}{r}.9904 \\
(1.0281)\end{array}$ \\
\hline$\Delta$ Consensus Demo ${ }_{t-1}$ & $\begin{array}{r}.9454 \\
(.8577)\end{array}$ & $\begin{array}{r}.9712 \\
(.8348)\end{array}$ & $\begin{array}{r}1.0664 * \\
(.8218)\end{array}$ & $\begin{array}{r}.8946 \\
(.8075)\end{array}$ & $\begin{array}{r}.9508 \\
(.8076)\end{array}$ & $\begin{array}{l}1.0046 \\
(.7991)\end{array}$ & $\begin{array}{r}2.2380^{* * *} \\
(1.1155)\end{array}$ \\
\hline $\begin{array}{l}\text { Institutional Veto } \\
\text { Points } \mathrm{t}_{-2}\end{array}$ & $\begin{array}{r}3.0200 * * \\
(1.3040)\end{array}$ & $\begin{array}{r}2.7979 * * \\
(1.2669)\end{array}$ & $\begin{array}{r}2.1698 * * \\
(1.2125)\end{array}$ & $\begin{array}{r}2.4663 * * \\
(1.1712)\end{array}$ & $\begin{array}{l}1.5855^{*} \\
(1.1769)\end{array}$ & $\begin{array}{r}1.9599 * * \\
(1.1917)\end{array}$ & $\begin{array}{r}3.4284 * * \\
(1.3655)\end{array}$ \\
\hline $\begin{array}{l}\Delta \text { Institutional Veto } \\
\text { Points } \\
t-1\end{array}$ & $\begin{array}{l}2.8560^{*} \\
(1.9093)\end{array}$ & $\begin{array}{r}2.03588^{*} \\
(1.9268)\end{array}$ & $\begin{array}{l}2.6622 * \\
(1.9134)\end{array}$ & $\begin{array}{l}2.5848^{*} \\
(1.8947)\end{array}$ & $\begin{array}{l}2.4815^{*} \\
(1.8713)\end{array}$ & $\begin{array}{l}2.5128^{*} \\
(1.8986)\end{array}$ & $\begin{array}{r}4.7202^{* * *} \\
(1.8536)\end{array}$ \\
\hline $\begin{array}{l}\text { Ideology -Median } \\
\text { Voter }_{\mathrm{t}-2}\end{array}$ & $\begin{array}{r}.0336^{* * *} \\
(.0171)\end{array}$ & $\begin{array}{r}.0306 * * \\
(.0170)\end{array}$ & $\begin{array}{r}-.3089 * * \\
(.1376)\end{array}$ & $\begin{array}{l}.0239^{*} \\
(.0170)\end{array}$ & $\begin{array}{l}.0271^{*} \\
(.0169)\end{array}$ & $\begin{array}{l}-.2334 \\
(.1496)\end{array}$ & $\begin{array}{r}.0664 * * \\
(.0245)\end{array}$ \\
\hline $\begin{array}{l}\Delta \text { Ideology -Median } \\
\text { Voter }_{\mathrm{t}-1}\end{array}$ & $\begin{array}{r}.0405 \\
(.0379)\end{array}$ & $\begin{array}{r}.0429 \\
(.0376)\end{array}$ & $\begin{array}{l}.0549^{*} \\
(.0380)\end{array}$ & $\begin{array}{r}.0413 \\
(.0374)\end{array}$ & $\begin{array}{r}.05118^{*} \\
(.0376)\end{array}$ & $\begin{array}{l}.0520^{*} \\
(.0381)\end{array}$ & $\begin{array}{r}.1234 * * \\
(.0528)\end{array}$ \\
\hline $\begin{array}{l}\text { Right Government } \\
\text { t-4 to t-2 }\end{array}$ & $\begin{array}{r}.0020 \\
(.0038)\end{array}$ & $\begin{array}{r}.0021 \\
(.0040)\end{array}$ & $\begin{array}{r}.0022 \\
(.0039)\end{array}$ & $\begin{array}{r}.0031 \\
(.0039)\end{array}$ & $\begin{array}{r}.0023 \\
(.0039)\end{array}$ & $\begin{array}{r}.0029 \\
(.0038)\end{array}$ & $\begin{array}{l}.0066 \\
(.0048)\end{array}$ \\
\hline $\begin{array}{l}\Delta \text { Right Government } \\
\text { t-4 to t-2 }\end{array}$ & $\begin{array}{r}.0117 \\
(.0094)\end{array}$ & $\begin{array}{r}.0112 \\
(.0093)\end{array}$ & $\begin{array}{r}.0124 \\
(.0094)\end{array}$ & $\begin{array}{r}.0112 \\
(.0094)\end{array}$ & $\begin{array}{r}.0110 \\
(.0094)\end{array}$ & $\begin{array}{r}.0119 \\
(.0094)\end{array}$ & $\begin{array}{l}.0182 \\
(.0116)\end{array}$ \\
\hline \multicolumn{8}{|l|}{ General Model } \\
\hline $\begin{array}{l}\text { Structural } \\
\text { Unemployment }{ }_{t-2}\end{array}$ & $\begin{array}{r}-.0125 \\
(.0198)\end{array}$ & $\begin{array}{r}-.0146 \\
(.0201)\end{array}$ & $\begin{array}{r}-.0049 \\
(.0206)\end{array}$ & $\begin{array}{l}-.0118 \\
(.0194)\end{array}$ & $\begin{array}{l}-.0120 \\
(.0197)\end{array}$ & $\begin{array}{l}-.0064 \\
(.0202)\end{array}$ & $\begin{array}{r}.3080 \\
(.0355)\end{array}$ \\
\hline $\begin{array}{l}\Delta \text { Structural } \\
\text { Unemployment }{ }_{\mathrm{t}-1}\end{array}$ & $\begin{array}{l}-.0385 \\
(.0339)\end{array}$ & $\begin{array}{l}-.0419 \\
(.0335)\end{array}$ & $\begin{array}{r}-.0343 \\
(.333)\end{array}$ & $\begin{array}{l}-.0420 \\
(.0331)\end{array}$ & $\begin{array}{l}-.0366 \\
(.0332)\end{array}$ & $\begin{array}{l}-.0378 \\
(.0332)\end{array}$ & $\begin{array}{r}.0029 \\
(.0628)\end{array}$ \\
\hline
\end{tabular}




\begin{tabular}{|c|c|c|c|c|c|c|c|}
\hline \multirow[b]{2}{*}{ Public Sector Debt $t_{\mathrm{t}-2}$} & \\
\hline & $\begin{array}{r}.0314 * * \\
(.0115)\end{array}$ & $\begin{array}{r}.0308 * * \\
(.0116)\end{array}$ & $\begin{array}{r}.0204 * * \\
(.0111)\end{array}$ & $\begin{array}{r}.0264 * * \\
(.0119)\end{array}$ & $\begin{array}{r}.0279 * * \\
(.0117)\end{array}$ & $\begin{array}{r}.0197 * * \\
(.0117)\end{array}$ & $\begin{array}{r}.0067 \\
(.0156)\end{array}$ \\
\hline $\begin{array}{l}\Delta \text { Public Sector } \\
\text { Debt }_{t-1}\end{array}$ & $\begin{array}{r}.0517 \\
(.0418)\end{array}$ & $\begin{array}{r}.0396 \\
(.0409)\end{array}$ & $\begin{array}{r}.0437 \\
(.0409)\end{array}$ & $\begin{array}{r}.0409 \\
(.0404)\end{array}$ & $\begin{array}{r}.0417 \\
(.0404)\end{array}$ & $\begin{array}{r}.0380 \\
(.0403)\end{array}$ & $\begin{array}{r}.0333 \\
(.0602)\end{array}$ \\
\hline $\begin{array}{l}\text { Percent Change Real } \\
\text { Profits }_{\mathrm{t}-2}\end{array}$ & $\begin{array}{r}.0558 \\
(.0576)\end{array}$ & $\begin{array}{l}.0649 \\
(.0573)\end{array}$ & $\begin{array}{r}.1018 * * \\
(.0567)\end{array}$ & $\begin{array}{r}.0705 \\
(.0565)\end{array}$ & $\begin{array}{r}.0674 \\
(.0568)\end{array}$ & $\begin{array}{r}.1002 * * \\
(.0512)\end{array}$ & $\begin{array}{r}.0586 \\
(.7060)\end{array}$ \\
\hline $\begin{array}{l}\Delta \text { Percent Change } \\
\text { Real Profits } \mathrm{s}_{\mathrm{t}-1}\end{array}$ & $\begin{array}{r}.0526 \\
(.0415)\end{array}$ & $\begin{array}{l}.0574 * \\
(.0410)\end{array}$ & $\begin{array}{r}.0670 \\
(.0402)\end{array}$ & $\begin{array}{l}.0602 * \\
(.0403)\end{array}$ & $\begin{array}{l}.0574^{*} \\
(.0463)\end{array}$ & $\begin{array}{r}.0687 * * \\
(.0397)\end{array}$ & $\begin{array}{r}.1733 * * \\
(.0545)\end{array}$ \\
\hline $\begin{array}{l}\text { Domestic } \\
\text { Investment }-2\end{array}$ & $\begin{array}{r}.0115 \\
(.0432)\end{array}$ & $\begin{array}{r}.0058 \\
(.0424)\end{array}$ & $\begin{array}{r}.0141 \\
(.0411)\end{array}$ & $\begin{array}{r}.0130 \\
(.0416)\end{array}$ & $\begin{array}{r}.0114 \\
(.04170\end{array}$ & $\begin{array}{r}.0143 \\
(.0404)\end{array}$ & $\begin{array}{l}-.0663 \\
(.0654)\end{array}$ \\
\hline $\begin{array}{l}\Delta \text { Domestic } \\
\text { Investment } t_{-1}\end{array}$ & $\begin{array}{l}-.0163 \\
(.0296)\end{array}$ & $\begin{array}{r}-.0191 \\
(.02860\end{array}$ & $\begin{array}{l}-.0119 \\
(.0282)\end{array}$ & $\begin{array}{l}-.0188 \\
(.0279)\end{array}$ & $\begin{array}{l}-.0198 \\
(.0278)\end{array}$ & $\begin{array}{r}-.0150 \\
(.0272)\end{array}$ & $\begin{array}{r}-.0139 \\
(.0367)\end{array}$ \\
\hline $\begin{array}{l}\text { Growth Per Capita } \\
\text { Real GDP }{ }_{t-2}\end{array}$ & $\begin{array}{r}.1642 \\
(.1430)\end{array}$ & $\begin{array}{r}.1564 \\
(.1438)\end{array}$ & $\begin{array}{r}.1310 \\
(.1380)\end{array}$ & $\begin{array}{r}.1271 \\
(.1427)\end{array}$ & $\begin{array}{r}.1344 \\
(.1432)\end{array}$ & $\begin{array}{r}.1142 \\
(.01395)\end{array}$ & $\begin{array}{r}.4721 * * \\
(.2132)\end{array}$ \\
\hline $\begin{array}{l}\Delta \text { Growth Per Capita } \\
\text { Real GDP }{ }_{t-1}(\times 100)\end{array}$ & $\begin{array}{r}-.0008 \\
(.0032)\end{array}$ & $\begin{array}{l}-.0007 \\
(.0033)\end{array}$ & $\begin{array}{l}-.0003 \\
(.0036)\end{array}$ & $\begin{array}{l}-.0009 \\
(.0033)\end{array}$ & $\begin{array}{l}-.0007 \\
(.0035)\end{array}$ & $\begin{array}{l}-.0003 \\
(.0036)\end{array}$ & $\begin{array}{r}-.0008 \\
(.0018)\end{array}$ \\
\hline Tax Rate t-1 $_{1}$ & $\begin{array}{r}-.2446 * * \\
(.0341)\end{array}$ & $\begin{array}{r}-.2412^{* * *} \\
(.0350)\end{array}$ & $\begin{array}{r}-.2522 * * \\
(.0326)\end{array}$ & $\begin{array}{r}-.2436 * * \\
(.0324)\end{array}$ & $\begin{array}{r}-.2530 * * \\
(.0338)\end{array}$ & $\begin{array}{r}-.2500^{* * *} \\
(.0321)\end{array}$ & $\begin{array}{r}-.3900 * * \\
(.0496)\end{array}$ \\
\hline Fixed Effects & Yes & Yes & Yes & Yes & Yes & Yes & Yes \\
\hline Constant & 8.0368 & 7.1371 & 23.2973 & 6.1224 & 6.7376 & 18.3051 & -.7837 \\
\hline Observations & 469 & 469 & 469 & 469 & 469 & 469 & 365 \\
\hline $\mathrm{R}^{2}$ & .2234 & .2338 & .2572 & .2560 & .2625 & .2720 & .3232 \\
\hline
\end{tabular}

Statutory corporate tax models are estimated with 1982-2008 data by OLS for 17 nations (full sample without U.S.) The effective tax rate model of the last column is estimated with 1982-2005 data for 16 nations. The table reports OLS unstandardized regression coefficients and panel correct standard errors (Beck and Katz 1996).

* indicates significance at the .10 level or below.

** indicates significance at the .05 level or below. 